\title{
Role of Magnetic Resonance Imaging in the Evaluation of Spinal Dysraphism
}

RAMANNA CHANNEGOWDA HOSAGAVI', VENKAT GUNDAPPA MASIMADE², KS KISHORE $^{3}$

\section{ABSTRACT}

Introduction: Spinal dysraphism includes spectrum of congenital fusion anomalies of one or more dorsal midline structures including skin, subcutaneous tissue, vertebrae, meninges and neural tissue. It is due to incomplete midline closure of the bony and neural spinal tissues. Magnetic resonance imaging (MRI) is now considered to be the imaging modality of choice.

Aim: To assess the role of MRI in the evaluation of spinal dysraphism and to assess the spectrum of lesions of spinal dysraphism.

Materials and Methods: The study was performed on 30 patients suspected of spinal dysraphism, over the time period from November 2016 to May 2018 in the Department of Radiodiagnosis in Victoria Hospital and Bowring and Lady Curzon Hospital attached to Bangalore Medical College and Research Institute, Bengaluru. All patients underwent MR imaging examination performed on a SIEMENS magneto 1.5-T MR system in Victoria hospital. Radiological characteristics and clinical features were studied. Descriptive and inferential statistical analysis was made. Results on categorical measurements are presented in Number (\%) and results on continuous measurements are presented on Mean \pm SD (MinMax).

Results: The ages of patients included in the study were in the range of 4 months-11 years with maximum number of patients were in the age group of $1-5$ years ( 43.3\%). Female preponderance was noted. Congenital spinal lesions without subcutaneous masses (43.3\%) were more common than the lesions with subcutaneous masses (30\%). Vertebral anomalies were the most common spinal anomalies in patients with congenital spinal lesions followed by spina bifida, tethered cord, scoliosis, syrinx and diastematomyelia. Of all the vertebral anomalies, spina bifida was the most common (73.3\%). Lumbosacral spine was most common site of involvement in 11 cases (36.65\%).

Conclusion: MRI does not involve ionizing radiation, has no biological risk, and avoids intrathecal injection of contrast media, it offers several advantages in the evaluation of children with suspected spinal dysraphism and help in accurate diagnosis.

\section{INTRODUCTION}

Spinal dysraphism includes spectrum of congenital fusion anomalies of one or more dorsal midline structures including osseous, mesenchymal and nervous tissue [1,2]. Clinical description of spinal dysraphism was made by Lichtenstein BW and James CC et al., [3,4].

Early imaging approaches were based on the use of conventional Radiography, Ultrasonography (USG) and Computerized tomography (CT) $[5,6]$. MRI of spinal dysraphism is first described by Barnes PD et al., [7]. Spinal dysraphism is one of the most common congenital disorders associated with significant mortality and morbidity. The estimated incidence of spinal dysraphism is about 1-3/1000 live births [8]. About $55-70 \%$ of neural tube defects occur in females. Variations in prevalence based on race, ethnicity, gender and region have also been reported [9,10]. The prevalence of neural tube defects (including anencephaly and spinal dysraphisms) has been on the decline during the last 25 years as a result of antenatal screening and folic acid supplementation [10]. Majority of the closed spinal dysraphic states are asymptomatic at birth. They are suspected in the presence of high risk cutaneous markers, or when these children present with neurological deficit later in life [11].

$\mathrm{MRI}$ is the assessment of choice because of its better investigative performance, exceptional soft tissue characterization and importance in presurgical planning [8]. MRI is the imaging modality of choice in the diagnosis and characterization of spinal dysraphism. Rest of the modalities play a supplemental role. Antero-posterior and lateral plain radiographs are a must for evaluation of the vertebral column [12,13].

In cases of diastematomyelia, bony spur may be seen. Radiographs are used as screening examinations to guide the further imaging work-up. Ultrasonography is useful in the antenatal diagnosis of spinal dysraphism and is also of some use in the neonate and infant $[14,15]$. During the first year of life it becomes progressively less useful as ossification of posterior elements proceeds. Prenatal ultrasonography can detect the open widened neural arch, with flared laminae, can show the meningomyelocele sac and detect hydrocephalus and associated cranial anomalies. Direct ultrasonography of the sac in children using high frequency transducers gives information about the contents of the sac. But, for complete and detailed information, an MRI scan is often required. In cases of split cord malformation, CT is useful in demonstration of the bony spur. Prior to the advent of MRI, myelography and postmyelogram CT were used. MRI gives a non-invasive and accurate method to evaluate spinal dysraphism, thus making it the modality of choice. The excellent contrast resolution, wide field of view and multiplanar images help evaluate the entire spinal cord, contents of the back mass; detect cord tethering, associated syringomyelia. For the demonstration of syrinx and associated pathologies like dermoid and epidermoid cyst, T2W images are helpful $[13,16]$. Patients with spinal dysraphism can have multiple spinal anomalies. For example, a patient with myelomeningocele may have associated chiari malformation or syringohydromyelia. Fetal MRI may be used as complimentary modality to USG for the antenatal diagnosis of spinal anomalies and associated hydrocephalus $[14,15]$.

\section{MATERIALS AND METHODS}

The present observational study was performed on 30 patients suspected of spinal dysraphism based on clinical examination, over the time period from November 2016 to May 2018; in the Department of Radiodiagnosis in Victoria Hospital and Bowring and Lady Curzon Hospital attached to Bangalore Medical College and Research Institute, Bengaluru. The permisson to conduct the study was obtained from Institutional Ethical Committe via letter number BMC/PGS/289/2016- 
17 Newborn-12 years old suspected to have spinal dysraphism and patient diagnosed to have physical abnormality caused by congenital lesions of spinal cord and cauda equina were included and patients with anencephaly and patients with physical abnormality caused due to spinal neoplasms, Friedreich's ataxia, cerebral palsy, old poliomyelitis and local conditions of the feet were excluded.

All patients included in the study or their guardians were explained of the procedure and informed consent was taken from them. All patients were screened for clips, cochlear implants etc. All MR imaging examination was performed on a SIEMENS magneto 1.5-T MR system. Neonates under 2 months of age were scanned during natural sleep. Majority of our patients (approximately 70\%) required sedation [17]. Cardio-respiratory monitoring with MR compatible equipment is necessary in each and every infant, whether sedated or not [18]. For imaging, the intraspinal components of paediatric spine, MRI is the imaging modality of choice. The standard spine imaging included sagittal, fast spin-echo T1- and T2-W (weighted) sequences.

Both axial T1-W and T2-W images were acquired. Group of axial images through disc level were not applied, unlike most adult spine imaging protocols, because degenerative disc disease is uncommon. Children with suspected spinal dysraphism and/or scoliosis routinely had axial T1-W images to detect lipomas of the filum terminale that may not be visible on sagittal imaging.

\section{STATISTICAL ANALYSIS}

Descriptive and inferential statistical analysis was used. Categorical measurements are presented in Number and percentages (\%) and results on continuous measurements are presented in Mean $\pm S D$ (Min-Max).

\section{RESULTS}

The ages of patients included in the study were in the range of 4 months- 11 years. Maximum numbers of patients were in the age group of 1-5 years which consisted of 13 patients, accounting for 43.3\% [Table/Fig-1].

\begin{tabular}{|l|c|c|}
\hline Age in years & No. of patients & $\%$ \\
\hline $0-1$ year & 8 & 26.7 \\
\hline 1-5 years & 13 & 43.3 \\
\hline$>5$ years & 9 & 30.0 \\
\hline Total & 30 & 100.0 \\
\hline [Table/Fig-1]: Age distribution of patients studied.
\end{tabular}

Out of 30 patients, 21 were female and 9 were male with strong female preponderance, Female: Male ratio 2.3:1 [Table/Fig-2].

\begin{tabular}{|l|c|c|c|c|}
\hline \multirow{2}{*}{ Gender } & \multicolumn{3}{|c|}{ Age in years } & \multirow{2}{*}{ Total } \\
\cline { 2 - 4 } & $0-1$ year & $1-5$ years & $>5$ years & \\
\hline Female & $7(87.5 \%)$ & $10(76.9 \%)$ & $4(44.4 \%)$ & $21(70 \%)$ \\
\hline Male & $1(12.5 \%)$ & $3(23.1 \%)$ & $5(55.6 \%)$ & $9(30 \%)$ \\
\hline Total & $8(100 \%)$ & $13(100 \%)$ & $9(100 \%)$ & $30(100 \%)$ \\
\hline
\end{tabular}

Swelling in the back was the most common clinical presentation. Out of 30 patients, 15 had swelling in the back accounting for $50 \%$ of all cases [Table/Fig-3].

\begin{tabular}{|l|l|c|c|}
\hline SI. No & \multicolumn{1}{|c|}{ Clinical features } & Number & Percentage (\%) \\
\hline 1 & Swelling in back & 15 & 50 \\
\hline 2 & Hyper trichosis & 1 & 3.33 \\
\hline 3 & Sacral dimple & 1 & 3.33 \\
\hline 4 & Lower limb weakness & 4 & 13.33 \\
\hline 5 & Urinary incontinence & 6 & 20 \\
\hline 6 & Dermal sinus & 3 & 10 \\
\hline
\end{tabular}

The [Table/Fig-4] shows different types of spinal dysraphism in relation to age distribution of the patients. The [Table/Fig-5] shows different types of spinal dysraphism in relation to age distribution of the patients. Spinal dysraphism can involve any segment of spine. The most common site was the lumbosacral region accounting for $36.66 \%$ of all cases [Table/Fig-6].

\begin{tabular}{|c|c|c|c|c|}
\hline \multirow[b]{2}{*}{ Variables } & \multicolumn{3}{|c|}{ Age in years } & \multirow[b]{2}{*}{$\begin{array}{l}\text { Total } \\
(n=30)\end{array}$} \\
\hline & $\begin{array}{c}0-1 \text { year } \\
(n=8)\end{array}$ & $\begin{array}{c}1-5 \text { years } \\
(n=13)\end{array}$ & $\begin{array}{c}>5 \text { years } \\
(n=9)\end{array}$ & \\
\hline Spina bifida & $8(100 \%)$ & $9(69.2 \%)$ & $5(55.6 \%)$ & 22 (73.3\%) \\
\hline Myelomeningocele & $5(62.5 \%)$ & $2(15.4 \%)$ & $1(11.1 \%)$ & $8(26.7 \%)$ \\
\hline Myelocele & $1(12.5 \%)$ & $1(7.7 \%)$ & $0(0 \%)$ & 2 (6.7\%) \\
\hline Lipomyelomeningocele & $1(12.5 \%)$ & $5(38.5 \%)$ & $3(33.3 \%)$ & 9 (30\%) \\
\hline Lipomyelocele & $0(0 \%)$ & $0(0 \%)$ & $0(0 \%)$ & $0(0 \%)$ \\
\hline Diastematomyelia & $2(25 \%)$ & $4(30.8 \%)$ & $4(44.4 \%)$ & $10(33.3 \%)$ \\
\hline
\end{tabular}

[Table/Fig-4]: Different type of spinal dysraphism distribution in relation to age distribution of patients studied.

\begin{tabular}{|c|c|c|c|c|}
\hline \multirow[b]{2}{*}{ Variables } & \multicolumn{3}{|c|}{ Age in years } & \multirow[b]{2}{*}{$\begin{array}{l}\text { Total } \\
(n=30)\end{array}$} \\
\hline & $\begin{array}{l}0-1 \text { year } \\
(n=8)\end{array}$ & $\begin{array}{c}1-5 \text { years } \\
(n=13)\end{array}$ & $\begin{array}{c}>5 \text { years } \\
(\mathrm{n}=9)\end{array}$ & \\
\hline Filar lipoma & $0(0 \%)$ & $1(7.7 \%)$ & $3(33.3 \%)$ & $4(13.3 \%)$ \\
\hline Dorsal dermal sinus & $0(0 \%)$ & $3(23.1 \%)$ & $0(0 \%)$ & $3(10 \%)$ \\
\hline Syrinx & $6(75 \%)$ & $12(92.3 \%)$ & $4(44.4 \%)$ & 22 (73.3\%) \\
\hline Tethered cord & $8(100 \%)$ & 9 (69.2\%) & $6(66.7 \%)$ & $23(76.7 \%)$ \\
\hline Sacral agenesis & $0(0 \%)$ & 3 (23.1\%) & 3 (33.3\%) & $6(20 \%)$ \\
\hline $\begin{array}{l}\text { Vertebral segmentation } \\
\text { anomalies }\end{array}$ & 2 (25\%) & 7 (53.8\%) & $3(33.3 \%)$ & $12(40 \%)$ \\
\hline Scoliosis & $3(37.5 \%)$ & $8(61.5 \%)$ & $3(33.3 \%)$ & $14(46.7 \%)$ \\
\hline
\end{tabular}

[Table/Fig-5]: Different type of spinal dysraphism distribution in relation to age distribution of patients studied.

\begin{tabular}{|l|l|c|c|}
\hline SI. No & Site involvement & Number & Percentage (\%) \\
\hline 1 & Cervical & 1 & 3.33 \\
\hline 2 & Thoracic & 2 & 6.66 \\
\hline 3 & Dorsolumbar & 3 & 10 \\
\hline 4 & Lumbar & 10 & 33.33 \\
\hline 5 & Lumbosacral & 11 & 36.66 \\
\hline 6 & Sacral & 3 & 10 \\
\hline TTable/Fig-6]: Site of involvement distribution of patients studied. \\
\hline
\end{tabular}

\begin{tabular}{|c|c|c|c|c|}
\hline \multirow[b]{2}{*}{ ACMII } & \multicolumn{3}{|c|}{ Age in years } & \multirow[b]{2}{*}{ Total } \\
\hline & 0-1 year & $1-5$ years & $>5$ years & \\
\hline Negative & $4(50 \%)$ & 12 (92.3\%) & $9(100 \%)$ & 25 (83.3\%) \\
\hline Positive & $4(50 \%)$ & $1(7.7 \%)$ & $0(0 \%)$ & 5 (16.7\%) \\
\hline Total & $8(100 \%)$ & 13 (100\%) & 9 (100\%) & 30 (100\%) \\
\hline
\end{tabular}

There were total 5 cases of Arnold chiari malformation type II, 4 in 0-1 age group and 1 in 1-5 years age group [Table/Fig-7]. Few examples are illustrated in [Table/Fig-8-16].

Of the 30 patients, 10 cases were of open spinal dysraphism with 8 cases presenting as myelomeningocele among which 5 cases were associated with Arnold chiari malformation II. Lumbosacral spine was most common location of myelomeningocele (5 cases) followed by 1 cervical and 1 sacral and 1 lumbar. Twenty patients were closed spinal dysraphism. Congenital spinal lesions without subcutaneous masses (43.3\%) were more common than the lesions with subcutaneous masses (30\%). Out of 10 cases of diastematomyelia, 6 were type 1 (60\%) and 4 were type 2 (40\%). Lumbosacral spine was most common site of involvement in 11 cases (36.65) followed by lumbar (33.3\%) and sacral spine (10\%) and dorsolumbar spine (10\%). 


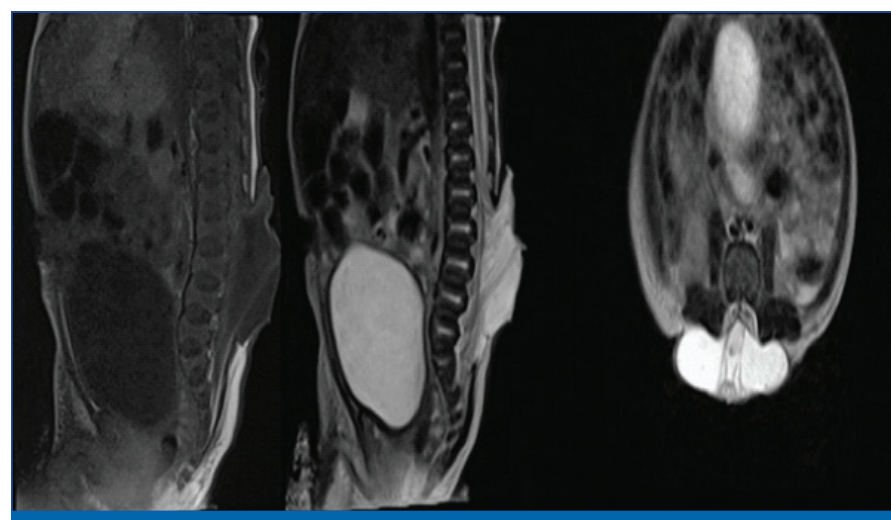

[Table/Fig-8]: Sagittal T1 and T2 W, Axial T2 W MR Images showing lumbosacral myelomeningocele.

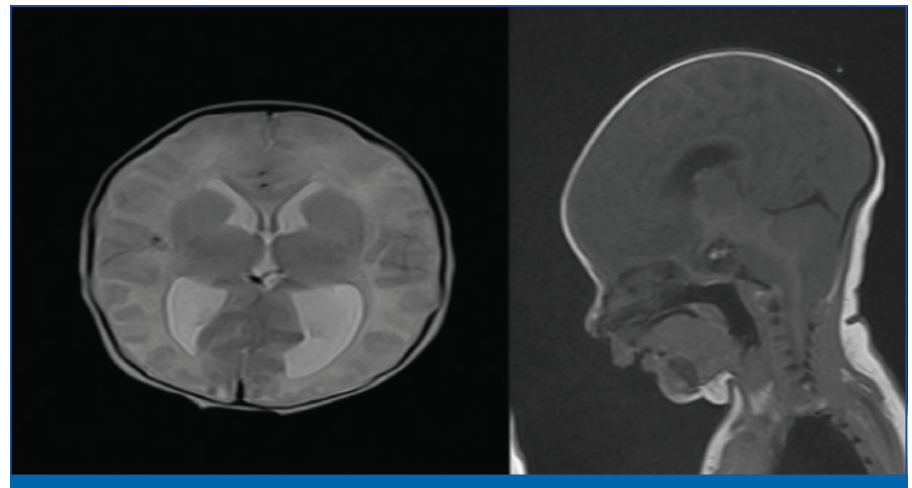

[Table/Fig-9]: Axial T2 W and Sagittal T1 W MR Image showing hydrocephalus and cerebellar tonsilar herniation (ACMII).

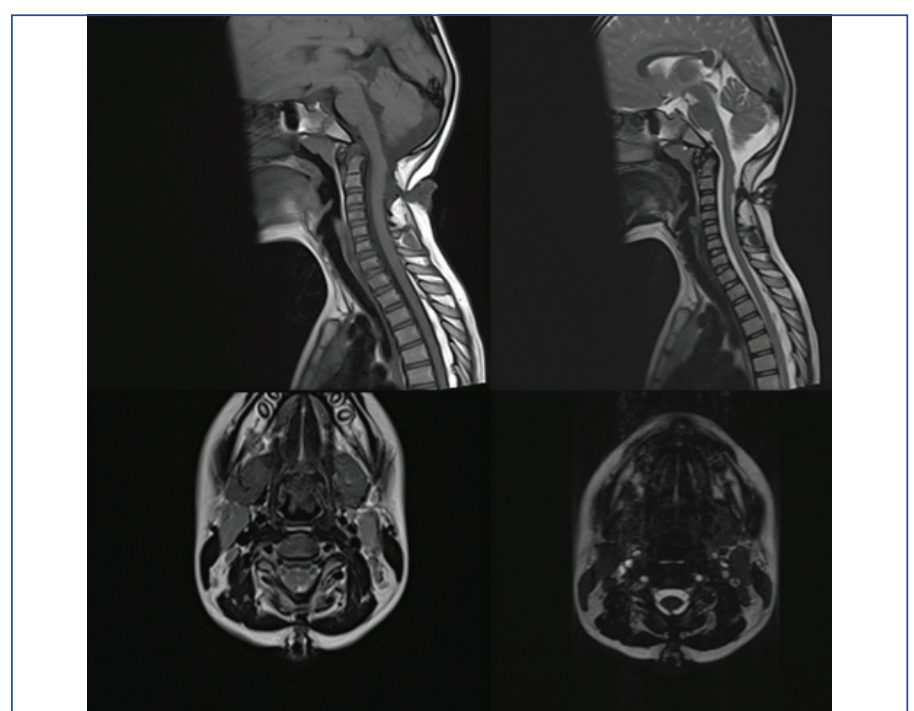

[Table/Fig-10]: Sagittal and Axial T1 and T2 W MR Images showing cervical myelomeningocele.

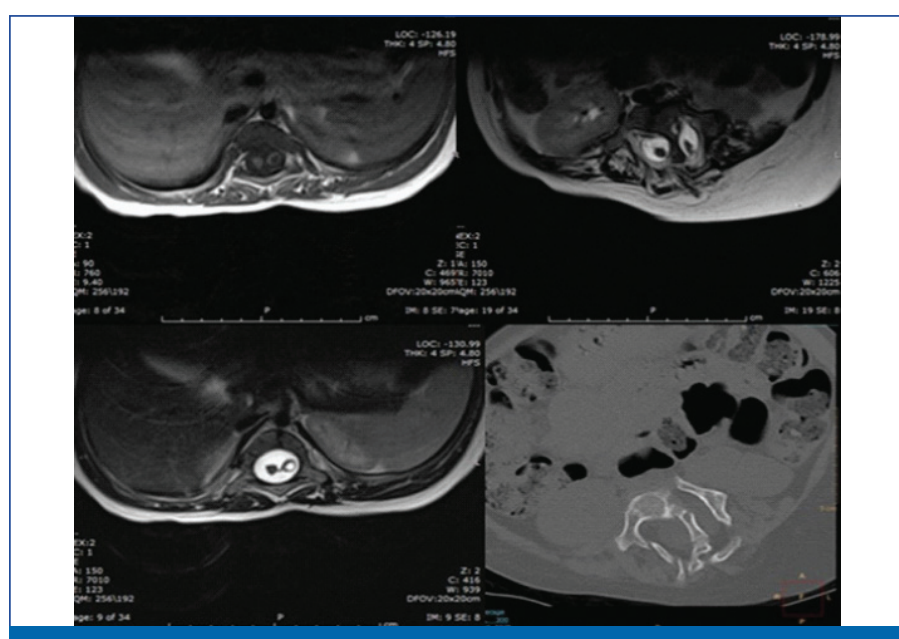

[Table/Fig-11]: Axial T1 and T2 W MR Images and axial CT image showing Type I diastematomyelia with dorsolumbar lipomyelomeningocele with syrinx in left hemicord.

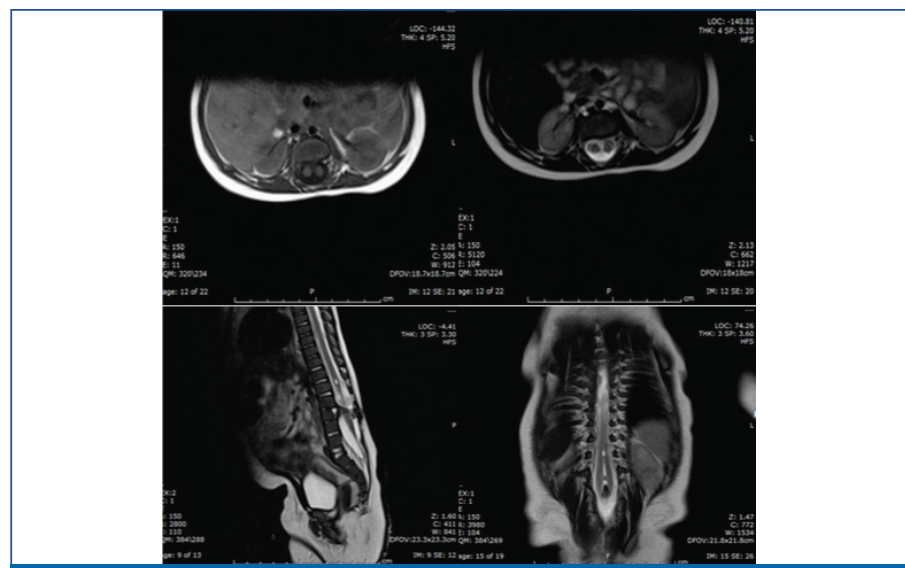

[Table/Fig-12]: Axial T1 and T2 W, sagitall T1 W and COR T2W MR Images Type 1 diastematomyelia with tethered cord and spina bifida in lumbosacral spine.
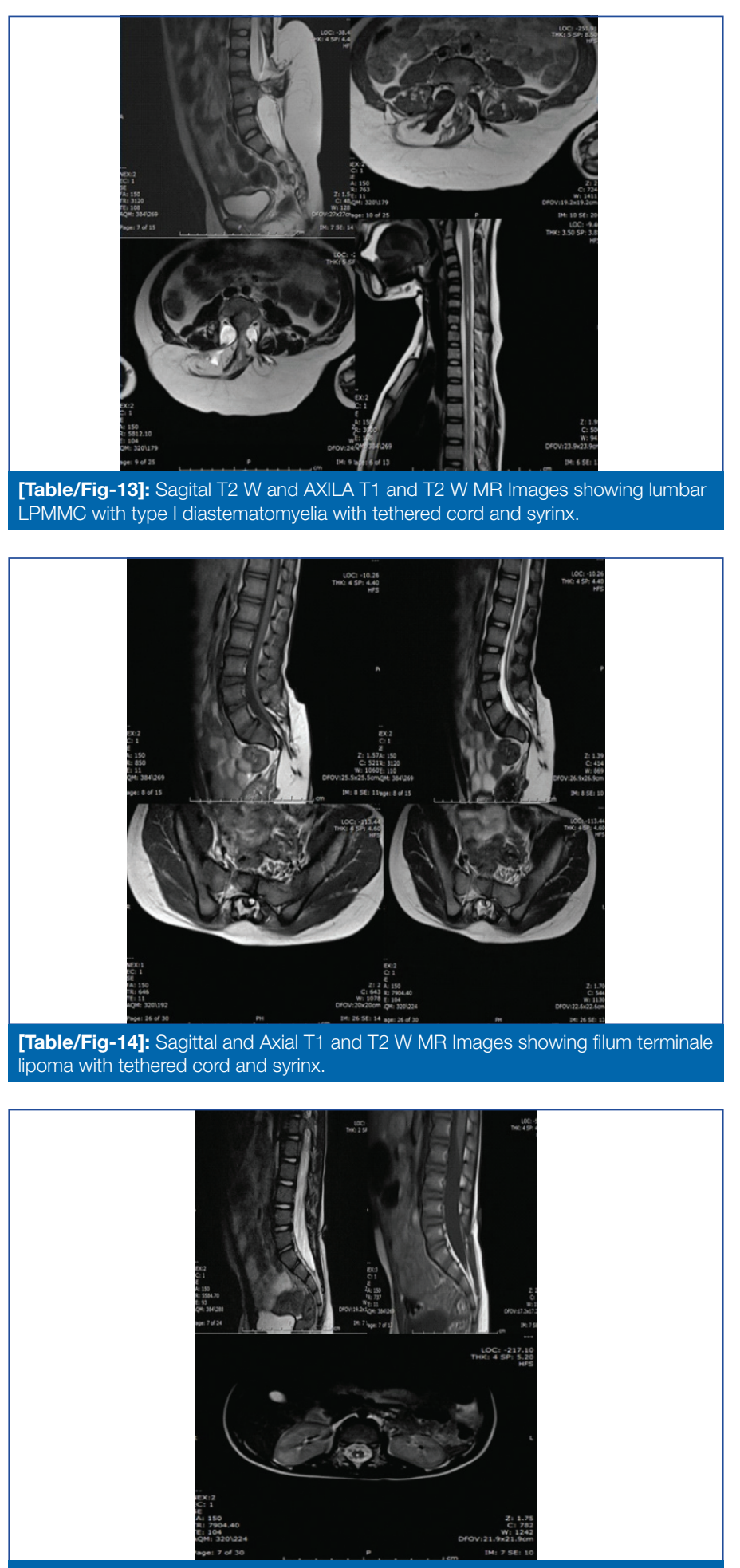

[Table/Fig-15]: Sagittal T1 and T2 W, Axial T2 MR Images showing dorsal dermal sinus with syrinx. 


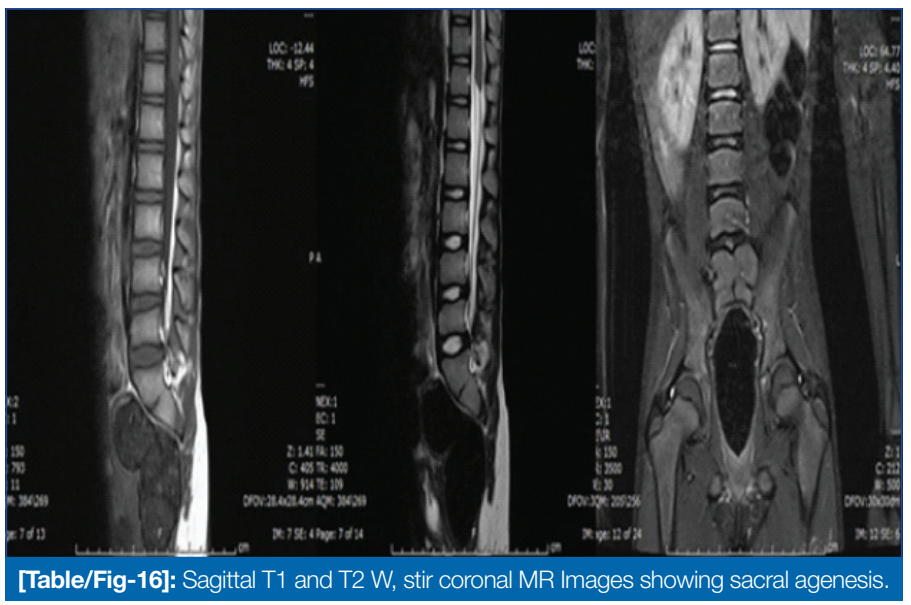

DISCUSSION

Spinal dysraphisms are the congenital abnormalities of the spine and spinal cord. In present study, the role of MRI in evaluation of suspected spinal dysraphism was studied. The age of the patients in present study ranged from 4 months to 11 years. Maximum number of patients were in the age group of 1-5 years, accounting for $\sim 43.3 \%$. In a study by Kumari MV et al., age of the patients ranged from 17 days to 13 years [8]. Most of the children are below 1 year of age and by Nafees $M$ et al., age of the patients ranged from 16 days to 37 years and most of them were below 6.4 years [19].

In this study out of 30 patients, 10 (33.33\%) had open spinal dysraphisms and 20 (66.66\%) had closed dysraphisms. The results were different to study by Kumari MV et al., in which 38 (57.5\%) were open spinal dysraphisms and 28 (42.4\%) were closed dysraphisms [8] Children of spinal dysraphism present with clinical features like swelling on the back, dermal sinus, haemangioma, dimple, lower limb weakness, and bowel and bladder incontinence. In this study, swelling in the back is the most common clinical feature which constituted 15 (50\%) patients. In a study by Kumari MV et al., also swelling in the back was the most common clinical feature which constituted 51 (77.2\%) patients [8]. Among different types of dysraphism, lipomyelomeningocele was the most common in closed spinal dysraphism which constituted 9 (30\%) and in open spinal dysraphism, myelomeningocele is most common, which constituted 8 (26.6\%). In a study by Kumari MV et al., myelomeningocele was the most common dysraphism which constituted 38 (57.5\%) [8]. In a study by Nafees $\mathrm{M}$ et al., also myelomeningocele is the most common dysraphism which constituted 29 (39.2\%) [19].

Location of myelomeningoceles of the 8 patients in this study were: one were noted in the cervical region, 1 in the lumbar region, 1 in the sacral region, 5 in lumbosacral region. In a study by Nafees $M$ et al., also lumbosacral region was the most common location which constituted 38 (51.4\%) and in study by Kumari MV et al., it was seen in $20(52.6 \%)$ patients $[8,19]$.

In this study, 10 (33.3\%) Diastematomyelia patients were detected, Of which type 2 constituted $40 \%$ and type 1 constituted $60 \%$. In a study by Kumari MV et al., 16 (24.2\%) Diastematomyelia patients were detected. Of which type 2 constituted $75 \%$ and type 1 constituted $25 \%$ and in a study by Nishtar T et al., of the 53 patients 2 (4\%) Diastematomyelia patients were detected [20].
Open defects are associated with abnormalities such as hydrocephalus, Arnold-Chiari, syrinx. In our study Arnold-Chiari type 2 constituted 5 (16.7\%). In a study by Kumari MV et al., ArnoldChiari type 2 constituted 6 (15.7\%) and In a study by Kumar R et al., Arnold-Chiari type 2 constituted 62 (45\%) patients [8,21].

\section{LIMITATION}

The number of cases included was limited. This small number could have potentially skewed the findings and age group $>12$ years was not included in this study, which could have resulted missing of cases with delayed presentation.

\section{CONCLUSION}

Imaging of spinal dysraphism is convoluted as various different conditions are involved in it which can have variable imaging appearance. An organized approach and MRI can helps in making the correct diagnosis as it does not involve ionizing radiation, is advanced and safe modality for assessing the spinal cord at all ages and defining complex spinal dysraphism.

\section{REFERENCES}

[1] Grainger R, Allison D, Adam A. Grainger's and Allison's diagnostic radiology. Newyork: Churchill Livingstone; 2001; 802-805.

[2] French B. The Embryology of Spinal Dysraphism. Neurosurgery. 1983;30(CN suppl_1):295-340.

[3] Lichtenstein BW. Spinal dysraphism: spina bifida and myelodysplasia. Arch neurol Psychiatry. 1940;44:792-810

[4] James CC, Lassman LP. Spinal dysraphism: an orthopaedic syndrome in children accompanying occult forms. Paediatric Radiol. 1960;35:315-27.

[5] Anderson FM. Occult spinal dysraphism: a series of 73 cases. Paediatric Radiol. 2011;55:826-35.

[6] Naidich TP, McLone DG, Mutluer SA. New understanding of dorsal dysraphism with lipoma (lipomyeloschisis): radiologic evaluation and surgical correction. AJR. 1983;140:1065-78.

[7] Barnes PD, Lester PD, Yamanashi WS, Prince JR. MRI in infants and children with spinal dysraphism. AJR. 1986;147:339-46.

[8] Kumari MV, Supriya P, Chandra Aemjal S, Raghavendra Y. Role of MRI in evaluation of suspected spinal dysraphism. Journal of Evolution of Medical and Dental Sciences. 2016;5(17):879-84.

[9] Shin M, Besser L, Siffel C, Kucik J, Shaw G, Lu C, et al. Prevalence of spina bifida among children and adolescents in 10 regions in the United States. Paediatrics. 2010;126(2):274-79.

[10] Badve C, Khanna P, Phillips G, Thapa M, Ishak G. MRI of closed spinal dysraphisms. Paediatric Radiology. 2011;41(10):1308-20.

[11] Drolet B. Birthmarks to worry about. Dermatologic Clinics. 1998;16(3):447-53.

[12] Tortori-Donati P, Rossi A, Cama A. Spinal dysraphism: a review of neuroradiological features with embryological correlations and proposal for a new classification. Neuroradiology. 2000;42(7):471-91.

[13] Tortori-Donati P, Rossi A, Biancheri R, Cama A. Magnetic Resonance Imaging of Spinal Dysraphism. Topics in Magnetic Resonance Imaging. 2001;12(6):375-409.

[14] Bulas D. Fetal evaluation of spine dysraphism. Paediatric Radiology. 2010;40(6):1029-37.

[15] Von Koch C, Glenn O, Goldstein R, Barkovich A. Fetal magnetic resonance imaging enhances detection of spinal cord anomalies in patients with sonographically detected bony anomalies of the spine. Journal of Ultrasound in Medicine. 2005;24(6):781-89.

[16] Rossi A, Biancheri R, Cama A, Piatelli G, Ravegnani M, Tortori-Donati P. Imaging in spine and spinal cord malformations. European Journal of Radiology. 2004;50(2):177-200.

[17] Sury M, Hatch D, Deeley T, Dicks-Mireaux C, Chong W. Development of a nurseled sedation service for paediatric magnetic resonance imaging. The Lancet. 1999;353(9165):1667-71.

[18] Sury M, Harker H, Begent J, Chong W. The management of infants and children for painless imaging. Clinical Radiology. 2005;60(7):731-41.

[19] Nafees M, Akram MH, Abbas G. MR image spectrum of spinal dysraphism in a military hospital. A Journal of Army Medical Corps. 2012;62(1):74-78.

[20] Nishtar T, Elahi A, lqbal N. To determine the frequency of accuracy of MRI in diagnosis of rare disorder of spinal dysraphism. J Med Sci (Peshawar, Print). 2011;19(4):195-99.

[21] Raj Kumar, Singh SN. Spinal dysraphism: Trends in Northern India Journal: Paediatric Neurosurgery - Paediat Neurosurg. 2003;38(3):133-145.

\section{PARTICULARS OF CONTRIBUTORS:}

1. Professor, Department of Radiology, Bangalore Medical College and Research Institute, Bangalore, Karnataka, India.

2. Postgraduate, Department of Radiology, Bangalore Medical College and Research Institute, Bangalore, Karnataka, India.

3. Postgraduate, Department of Radiology, Bangalore Medical College and Research Institute, Bangalore, Karnataka, India.

\section{NAME, ADDRESS, E-MAIL ID OF THE CORRESPONDING AUTHOR:}

Venkat Gundappa Masimade,

Room No-504, PG Mens Hostel Shivaji Nagar, Bangalore-560001, Karnataka, India.

E-mail: masimadevenkat@gmail.com

Date of Submission: Mar 11, 2019 Date of Peer Review: Apr 04, 2019 Date of Acceptance: Jul 17, 2019 Date of Publishing: Oct 01, 2019 